\title{
Arrest of Epidermal Growth Factor-dependent Growth in Fetal Hepatocytes after Ethanol Exposure
}

\author{
George I. Henderson, Gordon S. Baskin, Jean Horbach, Patricia Porter, and Steven Schenker \\ Departments of Pharmacology and of Medicine, Division of Gastroenterology and Nutrition, The University of Texas \\ Health Science Center at San Antonio, San Antonio, Texas 78284
}

\begin{abstract}
Exposure of the fetal rat hepatocyte to ethanol in vitro blocks epidermal growth factor (EGF)-dependent cell replication. To define possible mechanisms for this growth arrest, we determined the effects of ethanol on EGF binding and EGF receptor (EGF-R) levels. During a 24-h exposure to ethanol (1.7 $\mathrm{mg} / \mathrm{ml}, 31 \mathrm{mM}$ ), cell replication was completely blocked while EGF binding per cell doubled. This effect was not specific for EGF, with variable degrees of increased binding noted for insulin, transferrin, and glucagon. Significantly increased EGF binding was seen after $6 \mathrm{~h}$ of ethanol exposure, and both growth arrest and enhanced EGF binding were reversed within 12 h of ethanol withdrawal. Increases in both "high" and "low" affinity sites were seen, with no changes in the apparent $K_{d}$ 's. Total RNA, $\beta$-actin mRNA, and EGF-R mRNA were increased $50-70 \%$ in ethanol exposed cells. However, direct measurements of EGF-R synthesis rates by [ ${ }^{35}$ S]methionine incorporation revealed no differences between control and ethanol exposed cells. Internalization of EGF-R was significantly altered by ethanol exposure. A 2-h incubation resulted in the internalization of $57 \%$ of the ligand in control cells, while only $31 \%$ of bound EGF was internalized in the ethanol exposed cells. Thus, the enhanced EGF binding may be due to decreased efficiency of internalization.
\end{abstract}

\section{Introduction}

Since 1972, the term "fetal alcohol syndrome" has been used to describe the pattern of cranofacial, cardiac, and other developmental abnormalities associated with heavy maternal ethanol consumption $(1,2)$. While the complete spectrum of abnormalities has not been reproduced in any one animal model, numerous investigators have documented fetotoxic effects of maternal ethanol ingestion (3-6). Ubiquitous among these is reduced fetal weight which, in part, reflects impaired cell replication (5-7). To test this, we have used monolayer cultures of fetal hepatocytes from the Sprague-Dawley rat, a strain that exhibits well-documented fetal growth retardation with maternal alcohol exposure $(6,7)$. Our previous studies with this system have shown that ethanol exposure $(4 \mathrm{mg} / \mathrm{ml}$ for $24 \mathrm{~h}$ or

Address reprint requests to Dr. Henderson, Department of Medicine, Division of Gastroenterology and Nutrition, The University of Texas Health Science Center, 7703 Floyd Curl Drive, San Antonio, TX 78284-7878.

Received for publication 22 July 1988 and in revised form 5 June 1989.

J. Clin. Invest.

(C) The American Society for Clinical Investigation, Inc.

$0021-9738 / 89 / 10 / 1287 / 08 \quad \$ 2.00$

Volume 84, October 1989, 1287-1294 less) caused significant increases in cell protein, water and plasma membrane amino acid transport, yet resulted in a virtual block of epidermal growth factor (EGF) ${ }^{1}$-dependent cell replication (8). The studies reported herein focus on this latter effect at a more reasonable intrauterine ethanol concentration $(1.7 \mathrm{mg} / \mathrm{ml})$. The mechanisms underlying EGF-dependent mitogenesis are poorly understood, but one certainty is that EGF must first bind to the external domain of specific plasma membrane receptors for such a mitogenic response to occur (9). This, combined with the many documented effects of ethanol on cell membranes $(10,11)$, prompted a series of studies probing the effects of ethanol on initial EGF-receptor interactions. We document here an ethanol-induced derangement of EGF receptor expression reflecting, at least in part, perturbation of EGF-receptor internalization.

\section{Methods}

Cell culture. Fetal hepatocytes were obtained from Sprague-Dawley rats (Harlan Sprague-Dawley, Indianapolis, IN), isolated from the fetuses at the nineteenth day of gestation by collagenase digestion as previously described $(8,12)$. Hepatocytes were allowed to plate overnight on Primaria $35-\mathrm{mm}$ plates or $75 \mathrm{~cm}^{2}$ flasks (Falcon Plastics, Oxnard, CA) in William's essential (WE) custom culture medium without arginine (Irvine Scientific, Santa Ana, CA) supplemented with $10 \%$ dialyzed fetal calf serum. For subsequent refeedings, WE medium without arginine was supplemented with $2 \mathrm{ng} / \mathrm{ml} \mathrm{EGF}$ (Culture Grade, Collaborative Research Inc., Bedford, MA). No fetal calf serum was added. When ethanol was included, concentrations were maintained at $1.7 \mathrm{mg} / \mathrm{ml}$ by incubation in an ethanol atmosphere. Ethanol levels were constant as determined at various time points after refeeding (Stat-Pack ethyl alcohol test kit; Behring Diagnostics, La Jolla, CA). Ethanol exposure did not exceed $48 \mathrm{~h}$ and cultures were used within 72 $h$ of plating. This system has been extensively validated and consists of $>99 \%$ parenchymal cells that remain viable throughout the culture period $(8,12)$.

Immunoassay of EGF concentration. ELISA of EGF was performed in standard 96-well microtiter plates (Dynatech Laboratories, Alexandria, VA). The wells were coated overnight at $4^{\circ} \mathrm{C}$ with a 1:200 dilution of monoclonal anti-mouse EGF (kindly provided by Dr. Peter Ravdin) in $0.05 \mathrm{M} \mathrm{Na}_{2} \mathrm{CO}_{3}, \mathrm{pH}$ 9.0. The wells were then washed with PBS (150 mM NaCl, $5 \mathrm{mM}$ sodium phosphate, $\mathrm{pH} 7.4$ ) plus $0.05 \%$ Tween-20. $100 \mu \mathrm{l}$ of the standards (receptor grade EGF; Collaborative Research, Inc., Bedford, MA) and unknowns were incubated in the wells for $30 \mathrm{~min}$ at $37^{\circ} \mathrm{C}$. After washing with PBS-Tween, bound EGF was detected by the sequential addition of $100 \mu \mathrm{l}$ of 1:2,000 rabbit anti-mouse EGF (Cappel Laboratories, Organon-Technika, Malvern, PA) in PBS-Tween and 1:20,000 peroxidase conjugated goat anti-rabbit IgG (Cappel). Each was allowed to bind for $30 \mathrm{~min}$ at $37^{\circ} \mathrm{C}$, followed by washes with PBS-Tween. Bound peroxidase was assayed with $o$-phenylenediamine (13).

1. Abbreviations used in this paper: EGF, epidermal growth factor; FAS, fetal alcohol syndrome; PDGF, platelet-derived growth factor; WE, William's essential medium. 
EGF binding to fetal liver cells. EGF binding to the surface of fetal hepatocytes was determined at $4^{\circ} \mathrm{C}$ on monolayer cells on $35 \mathrm{~mm}$ Primaria plates. The plates were washed twice with PBS, then $1.5 \mathrm{ml}$ of binding medium (WE medium plus $1 \% \mathrm{BSA}$ ) containing 0.1 to $0.5 \mu \mathrm{Ci}$ of ${ }^{125}$ I-labeled EGF and added unlabeled EGF to achieve various final EGF concentrations. After the times indicated (usually $2 \mathrm{~h}$ ), the binding medium was aspirated and the cell monolayer washed five times with cold PBS. Bound radioiodine was determined by solubilizing the cells with $2 \mathrm{ml}$ of $2 \%$ SDS, $0.5 \mathrm{M} \mathrm{NaOH}$ and counting in a gamma counter (Beckman Instruments, Palo Alto, CA). Nonspecific binding was estimated in the presence of a 500 -fold excess of unlabeled EGF. This value was $<10 \%$ of specific binding and was not altered by ethanol exposure. Cell number per plate was determined in quadruplicate on parallel plates treated identically except no radiolabeled EGF was used. The cells were counted with a model ZM Coulter counter (Coulter Instruments, Hialeah, FL). Due to the previously observed changes in cell protein with ethanol exposure (8), binding is expressed as femtomoles EGF bound per $10^{4}$ cells. The time interval for binding equilibrium to be reached at $4^{\circ} \mathrm{C}$ was $2 \mathrm{~h}$ and was not affected by ethanol (Fig. $1 A$ and $B$ ). Acid stripping (see below) of the cells demonstrated that $>90 \%$ of the cell associated radioactivity was surface bound and equally acid labile in both control and ethanol exposed cells.

Binding of EGF to fetal liver cell membranes. Liver cell plasma membranes were prepared from fetal hepatocytes cultured in $75 \mathrm{~cm}^{2}$ Primaria flasks (Falcon). The monolayer was washed twice with cold PBS then briefly incubated with $25 \mathrm{mM}$ sucrose, $100 \mathrm{mM} \mathrm{NaCl}, 10$ mM Hepes, $1 \mathrm{mM}$ EDTA, pH 7.0, at $4^{\circ} \mathrm{C}$. The cells were removed with a rubber scraper and collected by centrifugation at $7,500 \mathrm{~g}$ for $15 \mathrm{~min}$. The pellet was then resuspended in $5 \mathrm{ml}$ of homogenization buffer $(250$ mM sucrose, $10 \mathrm{mM}$ Hepes, $1 \mathrm{mM}$ EDTA, $0.1 \mathrm{mM}$ PMSF, pH 7.4) and homogenized with 10 passes at high speed with a tight teflon homogenizer. The resulting homogenate was diluted to $30 \mathrm{ml}$ with homogenization buffer and centrifuged at $2,500 \mathrm{~g}$ for $10 \mathrm{~min}$ to remove unlysed cells. A plasma membrane enriched cell membrane fraction was prepared by a modification of the method of Blitzer and Donovan (14). The Percoll gradient fractions were diluted in PBS, collected by centrifugation, and resuspended in homogenization buffer.

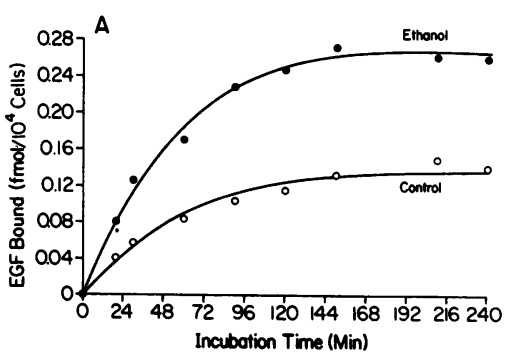

Figure 1. Effect of ethanol on EGF binding to fetal hepatocytes. EGF binding to fetal hepatocytes was determined after a $24-\mathrm{h}$ exposure to ethanol $(1.7 \mathrm{mg} / \mathrm{ml})$ with no ethanol present during binding $(A)$ or with ethanol present only during binding $(B)$.

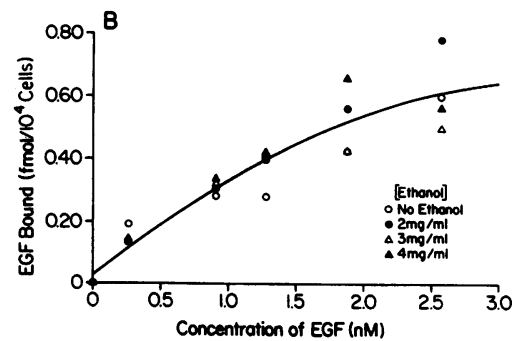

(A) Binding capacity was determined at $4^{\circ} \mathrm{C}$ with $2 \mathrm{ng} / \mathrm{ml} \mathrm{EGF}$. Each point represents the mean of four determinations with all ethanol values exceeding its corresponding control $(P<0.05)$. Standard errors did not

differ $>5 \%$ of the mean. $(B)$ Binding was measured after $2 \mathrm{~h}$ of incubation with various concentrations of EGF. Nonspecific binding (in the presence of 500-fold molar excess) was subtracted. Each value represents the average of four determinations. Ethanol and control values did not differ $(P>0.05)$.
For binding studies, $10-50 \mu \mathrm{g}$ of membrane protein was added to 1 $\mathrm{ml}$ of $100 \mathrm{mM} \mathrm{NaCl}, 10 \mathrm{mM}$ Hepes, $5 \mathrm{mM} \mathrm{CaCl}_{2}, 0.1 \mathrm{mM} \mathrm{MgCl}$, $0.01 \mathrm{mM}$ PMSF, $1 \mathrm{mg} / \mathrm{ml} \mathrm{BSA}$, pH 7.4, containing ${ }^{125}$ I-labeled EGF $(0.05-0.1 \mu \mathrm{Ci})$ and unlabeled EGF to achieve selected final concentrations of ligand. After $3 \mathrm{~h}$ at $4^{\circ} \mathrm{C}$, the mixture was filtered through a 0.2- $\mu \mathrm{m}$ GVWP Millipore filter (Millipore Corp., Waltham, MA) and the filter was washed 10 times with PBS. The filters were then dried and counted. Membranes incubated with 500 -fold excess of unlabeled ligand served as controls for nonspecific binding, which was $<20 \%$ of specific binding and $<0.3 \%$ of added counts.

$E G F$ receptor upregulation. Fetal hepatocytes were grown in WE medium containing $2 \mathrm{ng} / \mathrm{ml}$ of EGF with or without $1.7 \mathrm{mg} / \mathrm{ml}$ ethanol. After $24 \mathrm{~h}$ of exposure, the cells were washed twice with PBS and incubated with WE medium, with or without ethanol, containing EGF in concentrations from 0 to $2 \mathrm{ng} / \mathrm{ml}$. After $1 \mathrm{~h}$ at $37^{\circ} \mathrm{C}$, the cells were washed with PBS and the EGF binding assay was performed as described above. Parallel plates were treated identically and cell counts were performed to measure cell loss per plate during the washing steps. Initial experiments showed that fetal hepatocytes grown in $2 \mathrm{ng} / \mathrm{ml}$ EGF were maximally downregulated, upregulation was rapid and complete by $1 \mathrm{~h}$, and the process was inhibitable by cycloheximide (Fig. 2).

Biosynthesis of EGF receptor. Fetal hepatocytes were grown in 75 $\mathrm{cm}^{2}$ Primaria flasks with or without ethanol exposure for $24 \mathrm{~h}$. The culture medium was removed and replaced with WE medium, without arginine or methionine, containing $2 \mathrm{ng} / \mathrm{ml} \mathrm{EGF}$ and $50 \mu \mathrm{Ci} / \mathrm{ml}$ of $\left[{ }^{35}\right.$ S $]$ methionine (ICN Radiochemicals, Irvine, CA). After various labeling periods, the cells were washed twice with PBS and collected as above and solubilized in lysis buffer $(150 \mathrm{mM} \mathrm{NaCl}, 10 \mathrm{mM}$ Hepes, 5 mM EDTA, $1 \%$ Triton X-100, 0.1\% SDS, 0.1\% BSA, 0.1 mM PMSF, pH 7.0). Undissolved material was removed by centrifugation and the supernatant was treated with nonimmune mouse IgG and Affi-GelProtein A for $1 \mathrm{~h}$ at RT. After centrifugation, $5 \mu \mathrm{l}$ of monoclonal anti-EGF-R (monoclonal 29.1.1; ICN Immunobiologicals, Irvine, CA) was added to the supernatant and incubated at $4^{\circ} \mathrm{C}$ overnight, followed by precipitation with Affi-Gel-Protein A at RT for $1 \mathrm{~h}$. The beads were washed five times with the lysis buffer. The immunoprecipitated EGF-R was eluted by boiling the beads with $2 \%$ SDS, $2 \%$ 2-mercaptoethanol, $60 \mathrm{mM}$ Tris- $\mathrm{HCl}, \mathrm{pH} 6.8$, and subjected to electrophoresis on $6 \%$ polyacrylamide gels in the buffer system of Laemmli (15). The gel was dried, autoradiographed at $-70^{\circ} \mathrm{C}$ with Kodak RP X-Omat film, and the 185-kD band was identified and cut from the dried gel. The gel slice was rehydrated in $10 \%$ methanol, fragmented, hydrolyzed, and then counted in ACS (Amersham Corp., Arlington Heights, IL).

$R N A$ isolation and quantitation by dot-blot method. Cytoplasmic RNA was isolated from cultured hepatocytes as described by Gough (16). Whole cell lysates for direct blotting were prepared as described by Krawczyk and Wu (17). The cytoplasmic RNA content of the cultured hepatocytes was measured according to the method of Fleck

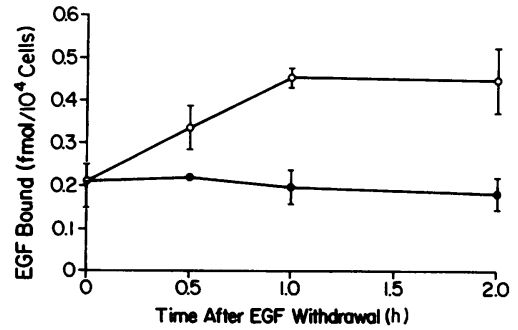

Figure 2. Effect of cycloheximide on EGF receptor upregulation. Cells were fully downregulated with $2 \mathrm{ng} / \mathrm{ml}$ EGF, then medium without EGF was added to initiate upregulation $\left(37^{\circ} \mathrm{C}\right)$. Plates with media containing cycloheximide ( $\bullet, 50 \mu \mathrm{g} / \mathrm{ml})$ were treated in parallel with controls (o). After the individual times, binding was assayed with a $2-\mathrm{h}$ incubation at $4^{\circ} \mathrm{C}$ with $2 \mathrm{ng} / \mathrm{ml}$ of EGF. Specific EGF binding to cycloheximide-exposed cells was significantly less $(P<0.05)$ than control values at each time point (five plates per point \pm SEM). 
and Munro (18). EGF-R specific and $\beta$-actin specific RNA sequences were determined by dot-blot hybridization to total RNA (19) or to whole cell lysates (17) using pE7 (American Type Culture Collection, Rockville, MD) as the EGF-R probe. For prehybridization and hybridization buffers, 5\% Bailey's Irish Cream in $2 \times$ SSC was used. After autoradiography, quantitation was performed using a Quick-Scan R \& D densitometer (Helena Laboratories, Helena, MN) and GS370 densitometry software (Hoeffer Scientific Instruments, San Francisco, CA).

$E G F$ internalization. Internalization experiments were performed similarly to those reported for asialoglycoprotein (20). Cells were first incubated with ${ }^{125} \mathrm{I}$-labeled EGF at $2 \mathrm{ng} / \mathrm{ml}$ for $3 \mathrm{~h}$ at $4^{\circ} \mathrm{C}$ as described above, then washed five times with cold PBS. Internalization was initiated by the addition of $2 \mathrm{ml}$ of warmed WE medium containing no added EGF followed by incubation at $25^{\circ} \mathrm{C}$. After the appropriate time interval, cells were washed twice with cold PBS, acid stripped (21) with $0.2 \mathrm{M}$ acetic acid, $0.5 \mathrm{M} \mathrm{NaCl}$ for $6 \mathrm{~min}$, and washed five times with cold PBS. Cell associated radioactivity was measured on the solubilized cells as described above. Total (surface bound plus internalized) EGF was measured in parallel plates before stripping. Parallel plates incubated with 500-fold excess cold EGF were used to estimate nonspecific binding and fluid phase pinocytosis. These values were always $<10 \%$ of total binding. Consistent with other reports, $7-12 \%$ of the cell bound radioactivity in plates with excess EGF could not be removed with the acid stripping technique $(21,22)$. This value was determined in each experiment and was subtracted from the surface binding and internalization estimates.

Transferrin, insulin, and glucagon binding. Determination of transferrin, insulin and glucagon binding were done identically to the procedure described for EGF. ${ }^{125} \mathrm{I}$-transferrin (Amersham Corp.) and unlabeled apotransferrin (Sigma Chemical Co.) were converted to the diferric form by addition of $\mathrm{FeCl}_{3}$ to a final concentration of $8 \mu \mathrm{M}$ at $\mathrm{pH}$ 7.4. Binding assays included $0.2-0.5 \mu \mathrm{M} / \mathrm{Ci}$ per $\mathrm{ml}$ of labeled transferrin and unlabeled transferrin to achieve the indicated concentrations. Labeled insulin and glucagon were from Amersham, unlabeled insulin from E. R. Squibb \& Co. (Princeton, NJ) and glucagon from Sigma Chemical Co.

General methods. Protein determinations were by the method of Lowry (23).

Statistical methods. Experimental data was analyzed by a one-way ANOVA with $P<0.05$ considered to be significant. Curve fitting of binding isotherms used a least squares method for both one- and twocomponent models (Enzfitter, Elsievier Software).

\section{Results}

Effects of EGF and ethanol on fetal hepatocyte replication. Fig. $3 \mathrm{~A}$ illustrates the dependence of fetal hepatocyte replication on EGF concentration in the culture medium. A concentration of $1 \mathrm{ng} / \mathrm{ml}$ (not shown here) resulted in no net increase in cell number, while levels up to $10 \mathrm{ng} / \mathrm{ml}$ caused no additional replication compared to the $2 \mathrm{ng} / \mathrm{ml}$ used under standard culture conditions. The use of insulin, glucagon, transferrin, or platelet-derived growth factor (PDGF) alone, or in combination with EGF, resulted in no enhancement of the growth response to EGF (data not shown). Addition of ethanol (1.7 $\mathrm{mg} / \mathrm{ml}$ ) to the culture medium blocked cell replication (Fig. 3 $B)$ and this inhibition could not be overcome by increased concentrations of EGF (8). The ethanol effect was also reversible. After $24 \mathrm{~h}$ of exposure, withdrawal of ethanol resulted in a resumption of cell division.

Effects of ethanol on EGF binding to the fetal hepatocyte. EGF binding at $4^{\circ} \mathrm{C}$ reached a steady state after $2 \mathrm{~h}$ and there was no significant increase in associated counts with longer incubations (Fig. $1 A$ ). EGF binding to fetal hepatocytes previously growth arrested by exposure to $1.7 \mathrm{mg} / \mathrm{ml}$ ethanol for
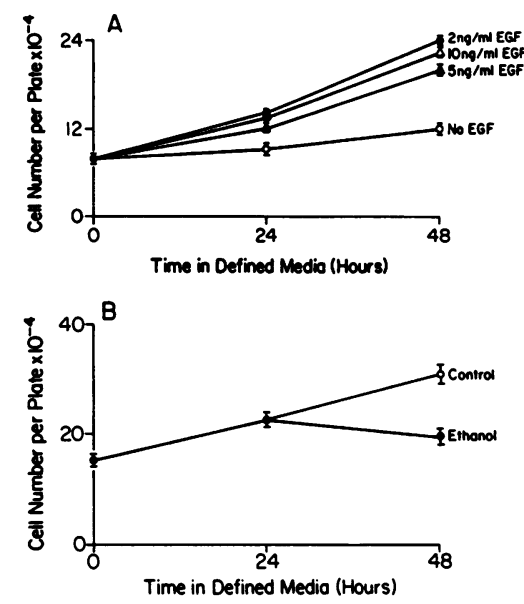

Figure 3. Effect of EGF and ethanol on fetal hepatocyte replication. $(A)$ Hepatocytes were plated overnight in WE medium containing $10 \%$ dialyzed fetal calf serum. The following morning WE medium, without serum but containing varying concentrations of EGF, was added and cell counts per 35-mm plate were determined in quadruplicate at 24-h intervals (mean \pm SEM). All values with EGF present exceeded those without added EGF $(P<0.05)$. (B) Subsequent experiments utilized $2 \mathrm{ng} / \mathrm{ml}$ EGF with ethanol exposure for $24 \mathrm{~h}$ and a concentration of $1.7 \mathrm{mg} / \mathrm{ml}$ over that period.

$24 \mathrm{~h}$ exceeded $(P<0.05)$ that to control cells by a median ratio of 2 (range 0.75 to $4 ; n=5$ plates/point). This was not a direct effect on the association of EGF with its receptor since no ethanol was present during the binding assay. In addition, inclusion of ethanol at concentrations up to $4 \mathrm{mg} / \mathrm{ml}$ only during binding produced no significant change in EGF binding for either control cells or for cells previously exposed to ethanol (Fig. $1 B$ ).

Onset and reversal of receptor overexpression. A significant increase in EGF binding to cells cultured in the presence of ethanol was observed only after $6 \mathrm{~h}$ of exposure (Fig. 4). For the next $18 \mathrm{~h}$, EGF binding continued to increase. If ethanolcontaining medium was replaced by standard culture medium without ethanol, EGF binding declined to control levels within $12 \mathrm{~h}$ of ethanol withdrawal.

Upregulation of EGF receptor. One explanation for the enhanced EGF binding following ethanol exposure could be upregulation of an otherwise normal receptor population. For a number of receptors, including EGF receptor, withdrawal of the ligand or reduction in receptor occupancy results in an

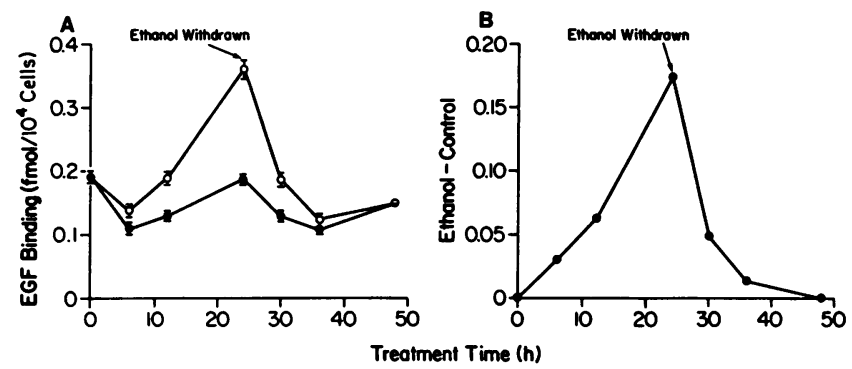

Figure 4. Rate of onset and reversal of the ethanol enhancement of EGF binding. Hepatocytes were maintained in defined medium with $2 \mathrm{ng} / \mathrm{ml} \mathrm{EGF}$ for $24 \mathrm{~h}$ before exposure to ethanol $(1.7 \mathrm{mg} / \mathrm{ml})$. Ethanol containing medium was introduced at time 0 and sets of plates were removed for assay of EGF binding. $(A)$ Ethanol values (O) exceeded $(P<0.05)$ control $(\bullet)$ at all time points (five plates/ point \pm SEM) except 12 and $24 \mathrm{~h}$ after withdrawal of ethanol. (B) Time course expressed as EGF binding in ethanol exposed cells minus that in control cells at various times of exposure. 
increase in receptor binding to the ligand (24). As shown in Fig. $1 B$, ethanol did not directly cause any decrease in binding to the receptor. The possibility that ethanol-exposed cells might metabolize EGF in the medium more rapidly than controls was also tested. ELISA of EGF concentration in the medium showed no differences in the levels of EGF after 12 to 24 $h$ in either group.

The ability of ethanol-treated hepatocytes to upregulate was then examined. Cells were initially in a downregulated state after culture for $24 \mathrm{~h}$ in medium containing $2 \mathrm{ng} / \mathrm{ml}$ EGF. This was replaced with WE medium containing 0.1 to $2.0 \mathrm{ng} / \mathrm{ml}$ EGF and the cells were incubated for $1 \mathrm{~h}$ at $37^{\circ} \mathrm{C}$, sufficient time for complete upregulation to occur (Fig. 2). EGF binding was measured in the usual fashion at an EGF concentration of $2 \mathrm{ng} / \mathrm{ml}$. The results are plotted as a function of EGF concentration during this upregulation period (Fig. 5). The range of EGF-induced modulation of the receptor was virtually identical for both groups, with the maximally upregulated state binding twice as much EGF in both instances. The shape of the response curve was nearly identical. The concentration of EGF which produced half-maximal upregulation was the same in both cases $(0.25 \mathrm{ng} / \mathrm{ml} ; 0.04 \mathrm{nM})$. The data confirm that the ethanol effect was not due to homologous upregulation of the EGF receptor as exposure of both experimental groups to defined EGF concentrations did not abolish the observed differences. The exposure to ethanol appeared to have altered the "set point" or minimum level of receptor for regulation of EGF-R on the cell surface.

Effect of ethanol on the EGF binding isotherm. To determine if the enhanced EGF binding observed above reflected an ethanol induced change in receptor affinity or receptor number, EGF binding to fetal hepatocytes was measured over a range of EGF concentrations from 0.01 to $10 \mathrm{nM}$. A Scatchard analysis of the binding isotherm was then employed to extract the relative receptor numbers and affinities (Fig. 6). For upregulated cells, the binding curves so derived show a definite curvilinear character, indicating that the receptor does not behave according to a simple, single site model. A nonlinear least-squares fit to a two-site model (Table I) yielded an apparent high affinity site with a $K_{\mathrm{d}}$ of $0.7 \pm 0.2 \mathrm{nM}$ and a low affinity site with $K_{d}$ of $10.2 \pm 2.7 \mathrm{nM}$, numbers very similar to those

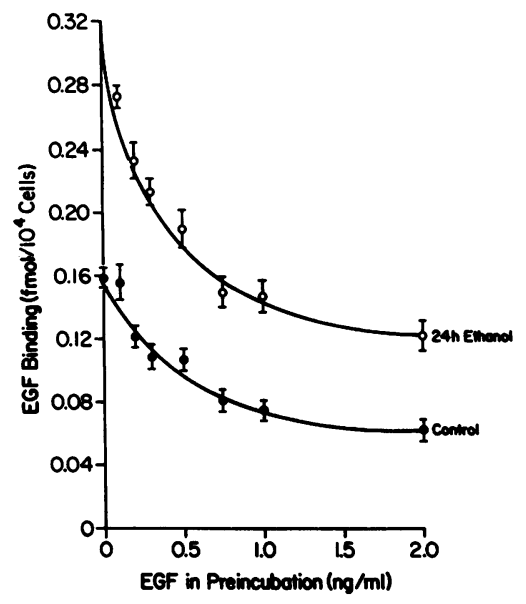

Figure 5. Upregulation of control and ethanolexposed cells. Fetal hepatocytes were maintained for $24 \mathrm{~h}$ in WE medium containing 2 $\mathrm{ng} / \mathrm{ml}$ EGF with ethanol $(1.7 \mathrm{mg} / \mathrm{ml})$ or without. Medium containing 0-2 ng/ml EGF was then added to the previously downregulated cells. After $1 \mathrm{~h}$ at $37^{\circ} \mathrm{C}$, in media with various EGF concentrations, EGF binding and cell counts were determined (see Methods).

Value represents the mean \pm SEM of five plates per point. All ethanol values exceeded control $(P<0.05)$.

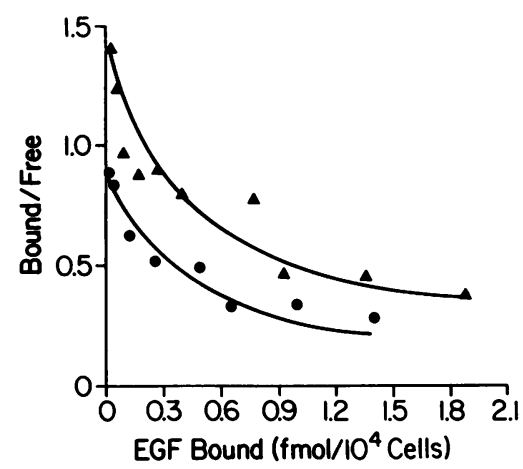

Figure 6. Scatchard plot of EGF binding to intact fetal hepatocytes. Hepatocytes were exposed to ethanol ( 1.7 $\mathrm{mg} / \mathrm{ml}, 24 \mathrm{~h}, \Delta)$ or control medium lacking EGF (•) and then were "upregulated" by a 60 min exposure to WE medium \pm ethanol. Binding was then determined as per Methods. Curves were fitted to a two-site model generated by a non-linear least-squares method. Results are shown in Table II. Each point is a mean of five values.

reported in other cell types (24). The number of such sites varied between isolations. For the high affinity site, each cell possessed an average of 30,500 receptors. The inclusion of ethanol in the binding assays resulted in no change in the derived binding isotherm, but in culture with $1.7 \mathrm{mg} / \mathrm{ml}$ ethanol for $24 \mathrm{~h}$, an increase in both high and low affinity sites was observed. On ethanol exposed cells, no significant change in the apparent affinity of the receptor sites for EGF was seen ( $K_{d}$ 's of $0.83 \pm 0.2$ and $9.1 \pm 2.5 \mathrm{nM}$ ). Both the high and low affinity sites showed a twofold increase in a given isolation.

Binding of EGF to plasma membrane enriched fractions from fetal hepatocytes confirmed the binding data from the cell monolayers. A similar curvilinear Scatchard plot was obtained (Fig. 7). The dissociation constants derived from a fit to a two-component model were similar to those found for the

Table I. Results of Two Component Fit for EGF Binding to Fetal Hepatocytes

\begin{tabular}{lcc}
\hline & \multicolumn{2}{c}{ Experimental group } \\
\cline { 2 - 3 } Parameter & Control & Ethanol \\
\hline Cell monolayers & & \\
High affinity & & $0.83 \pm 0.19$ \\
$K_{\mathrm{d}}$ & $0.73 \pm 0.19$ & $64,680 \pm 17,000$ \\
$n$ & $30,470 \pm 12,000^{*}$ & \\
Low affinity & $10.2 \pm 2.7$ & $9.1 \pm 2.5$ \\
$K_{\mathrm{d}}$ & $191,000 \pm 13,000^{*}$ & \\
$n$ & & \\
Plasma membranes & & $0.55 \pm 0.2$ \\
High affinity & & $1.9 \pm 0.4$ \\
$K_{\mathrm{d}}$ & & \\
$n$ & & $6.4 \pm 1.5$ \\
Low affinity & $1.3 \pm 0.3^{*}$ & $17.0 \pm 4.8$ \\
$K_{\mathrm{d}}$ & & \\
$n$ & $7.2 \pm 1.1$ & \\
\hline
\end{tabular}

$K_{\mathrm{d}}$ values in nanomoles per liter. $n$ (number of sites) is expressed as sites per cell for cell monolayers and as femtomoles of EGF bovine per milligram protein for plasma membranes. Numbers are given as mean \pm the standard deviation. The results are derived from five different isolations and determinations of the binding curve with each point measured in quadruplicate. ${ }^{*} P<0.05$ ethanol vs. control. 


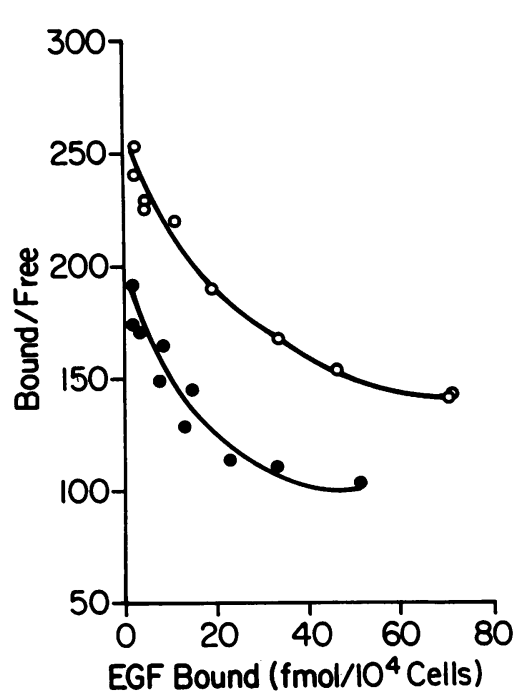

Figure 7. Scatchard plot of EGF binding to membrane fractions derived from fetal hepatocytes. Cells were treated as described in the legend for Fig. 6. Plasma membrane-enriched fractions were prepared from ethanol exposed (o) and control cells (๑) and specific EGF binding was determined as outlined in Methods.

Each point represents a mean of three values. Binding parameters and fitted curves were determined as in Fig. 6 and are presented in Table I.

whole cell. The number of sites per milligram membrane protein was increased for both high and low affinity receptor in the alcohol-exposed cells.

Biosynthesis of the EGF receptor. An increase in the synthesis of the EGF-R could explain the increased receptor number on ethanol exposed cell if the internalization process was not able to clear the cell surface of these additional receptors. The rate of synthesis and accumulation of "newly" synthesized EGF-R were estimated using incorporation of $\left[{ }^{35} S\right]-$ methionine into immunoprecipitable receptor. The number of counts in the mature $180-\mathrm{kD}$ receptor band on SDS PAGE was determined after various periods of labeling (Fig. 8). There did not appear to be a difference in free methionine accumulation between control and ethanol exposed cells as the number of soluble counts in the cell lysates was similar for both experimental groups. At early time points, methionine incorporation into EGF-R was not detectably different in the two cell groups. At later time points ( 12 and $24 \mathrm{~h}$, data not shown), ${ }^{35} \mathrm{~S}$ incorporation into the immunoprecipitated EGF-R was increased for ethanol exposed cells. With these long labeling times, however, the amount of labeled EGF-R does not reflect synthetic rate alone, but the size and balance of synthesis and degradation in the labeled receptor pool.

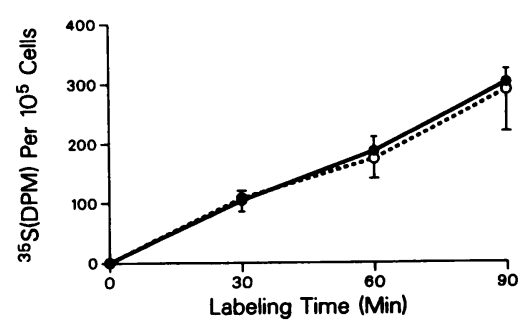

Figure 8. Rate of $\left[{ }^{35} \mathrm{~S}\right]-$ methionine incorporation into EGF receptor in control and ethanolexposed fetal hepatocytes. Fetal cells were cultured in WE me$\operatorname{dium} \pm 2 \mathrm{mg} / \mathrm{ml}$ of ethanol for $24 \mathrm{~h}$. At zero time, the cell mono-

layer was washed and the medium replaced with WE medium without methionine \pm ethanol containing $20 \mu \mathrm{Ci}\left[{ }^{35} \mathrm{~S}\right]$ methionine $/ \mathrm{ml}$. At the given time, the cells were washed, collected, solubilized, and the EGF receptor immunoprecipitated. After SDS PAGE of the immunoprecipitate, the gel was autoradiographed and the $180-\mathrm{kD}$ band was identified. The band was cut from the gel, and the labeled protein eluted for scintillation counting. Each point represents the mean and standard deviation of three or four experiments. ${ }^{*} P<0.05$, ethanol (०) vs. control (๑).
An additional measure of capacity for synthesis of EGF- $R$ is the availability of the mRNA for EGF-R. Dot blots indicated a $65 \%$ increase in both $\beta$-actin and EGF-R mRNA in whole cell lysates from ethanol-exposed cells (Table II). Direct measurement of RNA content revealed a 50\% increase in total RNA in fetal liver cells cultured for $24 \mathrm{~h}$ in the presence of ethanol $\left(30.6 \pm 6.4 \mu \mathrm{g} \mathrm{RNA} / 10^{6}\right.$ for control cells vs. $20.4 \pm 1.6$ for ethanol-treated cells). Dot blots performed with equal amounts of cytoplasmic RNA showed that the abundance of EGF-R mRNA was not detectably different (Table II).

Effect of ethanol on EGF internalization. Increased surface binding of EGF following ethanol exposure could be explained by impaired internalization of the EGF/receptor complex. To test this, rates of internalization of externally bound EGF were determined in a format that isolates these from the kinetics of surface binding. Fig. 9 illustrates both the rates and the absolute amount of EGF internalized by control and ethanoltreated hepatocytes. On control cells, the amount of surface bound EGF declined in an exponential fashion until $57 \%$ of the surface receptor-ligand complex had been internalized. The initial rate of uptake of the ligand was $1.2 \mathrm{fmol} / 10^{6} \mathrm{cells} /$ $\min$. After a 24-h exposure to ethanol at $1.7 \mathrm{mg} / \mathrm{ml}$, the initial rate of uptake was similar, but only $31 \%$ of the original EGFreceptor complex was internalized when a plateau was reached.

Effect of ethanol on transferrin, insulin, and glucagon binding to fetal hepatocytes. To determine if the effect of ethanol was specific for EGF receptor, levels of surface binding for three other ligands were measured. After $24 \mathrm{~h}$ of ethanol exposure, the binding of transferrin, insulin, and glucagon were increased by 107, 67, and 68\%, respectively (Fig. 10). The measured binding isotherm for insulin (Fig. 11) revealed essentially the same result as for EGF. The apparent affinity of the receptor was unchanged while the total amount of binding to the surface of the cells was increased.

\section{Discussion}

Ethanol is known to perturb a number of cellular processes such as transcription, protein synthesis, and protein secretion (25) which could result in reduced cell growth. In the case of fetal growth, work from our laboratory and others have documented inhibition of placental nutrient transport by chronic alcohol consumption $(26,27)$, which may also contribute to intrauterine growth retardation in fetal alcohol syndrome (FAS). Investigations of transmembrane amino acid and nutrient transport and the effects on fetal cells themselves are still incomplete, but no inhibitory effects have yet been reported (8). The principal intent of this report is to document the effects of ethanol directly on fetal cells and on the growth factor interactions required for replication of these cells. These studies indicate that $(a)$ exposure to moderate concentrations of ethanol blocks EGF-dependent replication of rat fetal hepatocytes in culture, $(b)$ ethanol exposure causes a progressive reversible increase in EGF-receptor number per hepatocyte, (c) the increase in EGF-receptor expression is associated with reduced fractional internalization of the EGF-receptor complex, and $(d)$ binding of other ligands to fetal hepatocytes is also enhanced by a 24-h exposure to ethanol. One potential common link between these receptors is their internalization via the coated pit, both as a functional carrier for receptor-mediated endocytosis and in receptor downregulation. Formal 


\begin{tabular}{llcccc}
\hline & & \multicolumn{2}{c}{ Abundance of mRNA (\% of control) } \\
\cline { 3 - 5 } & Total RNA & \multicolumn{2}{c}{$\beta$-Actin } & \multicolumn{2}{c}{ EGF-Receptor } \\
\hline & $\mu g / 10^{6}$ cells & per $\mu g$ RNA & per $10^{6}$ cells $\mu g$ RNA & per $10^{6}$ cells \\
Control & $20.4 \pm 1.6$ & 100 & 100 & 100 & 100 \\
Ethanol & $30.6 \pm 6.4^{*}$ & $99.3 \pm 8.2$ & $172 \pm 37^{*}$ & $103 \pm 13$ & $165 \pm 34^{*}$ \\
\hline
\end{tabular}

Numbers are means \pm standard deviations of four experiments. ${ }^{*} P<0.05$, ethanol vs. control. mRNA values are expressed relative to the amount of specific mRNA in control hepatocytes, either as mRNA per $\mu \mathrm{g}$ of cytoplasmic RNA or as mRNA per $10^{6}$ cells.

measures of internalization of insulin, transferrin, and other ligands have not yet been completed. However, this apparent nonspecific increase in binding of other ligands is consistent with yet another membrane related effect of ethanol on cells such as interference with coated pit function or other common mechanisms involved in receptor internalization.

Fetal and neonatal hepatocytes have previously been reported to replicate in response to $\operatorname{EGF}(8,28)$. Our data confirm this and further show that exposure to ethanol blocks this growth. The earliest potential site for a perturbation of the mitogenic response to EGF is at the first step in the process, binding of EGF to the membrane receptor. Ethanol did not directly (acutely) reduce binding of EGF to its receptor (Fig. 1 $B)$. Unexpectedly, EGF binding was doubled in the cells cultured for $24 \mathrm{~h}$ in ethanol. Subsequent experiments found this to be relatively slow in onset, requiring $6 \mathrm{~h}$ of ethanol exposure to significantly exceed control values, progressive with time and reversible on withdrawal of ethanol (Fig. 4). Several mechanisms were considered as an explanation for this phenome-

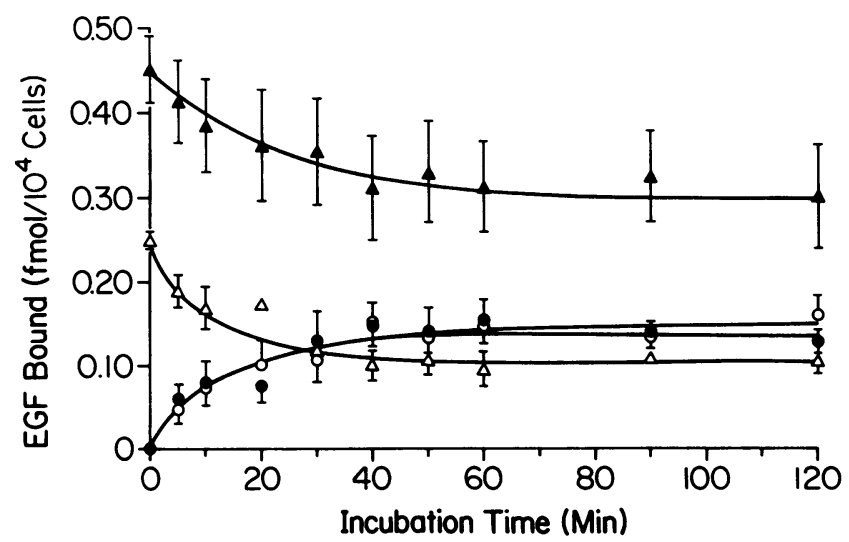

Figure 9. Effect of ethanol on internalization of the EGF receptor complex. Hepatocytes were upregulated by a 60 -min incubation in EGF-free medium then exposed to labeled EGF $(2 \mathrm{ng} / \mathrm{ml})$ for $3 \mathrm{~h}$ at $4^{\circ} \mathrm{C}$. Internalization was initiated by addition of warmed binding medium without EGF and incubation at $25^{\circ} \mathrm{C}$ continued for various intervals up to $2 \mathrm{~h}$. Internalized ${ }^{125} \mathrm{I}$ was determined by acid stripping as described in Methods. Ethanol-exposed cells were cultured in 1.7 $\mathrm{mg} / \mathrm{ml}$ ethanol for $24 \mathrm{~h}$ before the experiment. Each point represents the mean of five values \pm SEM. Both surface bound and internalized

${ }^{125}$ I are illustrated: $\Delta$ control-surface bound, $\Delta$ ethanol-surface bound; o control-internalized; $\bullet$ ethanol-internalized. $P<0.05$ ethanol vs. control for all surface bound points and $P>0.05$ for all internalized points. non, based on what is known about the regulation of EGF receptor levels. Increase in EGF binding assayed at a given ligand concentration could be due to an increase in the affinity of existing receptors and/or an increase in surface receptor number. The latter may occur via increased receptor synthesis, a redistribution of existing receptor to the cell surface, impaired internalization and degradation of the receptor, or some combination of these.

The role of a change in the affinity of the receptor resulting in increased binding was addressed by comparison of the binding isotherm for the two experimental groups. For both whole cells and cell membranes, such binding studies yielded curvilinear Scatchard plots. The data was fit to a two-component model and the numbers and dissociation constants of so-called high and low affinity binding sites were derived. There is no direct evidence that such distinct sites exist; indeed, cooperative binding behavior is a more likely explanation (24). Nevertheless, such an analysis is widely used. The effect of ethanol was to increase the number of both types of sites without any change in the affinity of these sites for EGF.

The data presented here also argue against a role for homologous up- or downregulation of EGF-R in the observed increase in ligand binding. Increase in receptor number on ligand withdrawal is a commonly observed phenomenon (24). Upregulation of EGF receptor number rapidly occurred on withdrawal of EGF in cultured fetal hepatocytes (Fig. 2), but the observed ethanol effect took more than $6 \mathrm{~h}$ to be manifest. A reduced occupancy of the EGF-R due to a direct effect of ethanol on ligand binding to the receptor could trigger such upregulation. Direct assay of the acute effects of ethanol on binding of EGF, however, revealed no such interference (Fig. 1 $B)$. If ethanol-exposed cells metabolized EGF more rapidly than control cells, EGF concentrations in the medium could

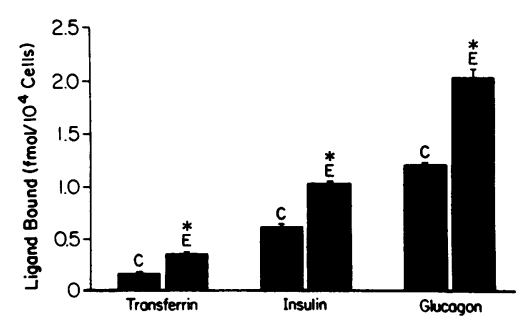

Figure 10. Effect of ethanol on transferrin, insulin, and glucagon binding to the fetal hepatocyte. Assays for transferrin, insulin and glucagon binding were done as described in Methods. Cells had no prior exposure to these ligands. Incubation with binding medium was for $2 \mathrm{~h}$. Ethanol-exposed cells were cultured in $1.7 \mathrm{mg} / \mathrm{ml}$ ethanol for $24 \mathrm{~h}$ before assay. Each bar represents the mean of five values \pm SEM. $C$, control, $E$, ethanol treated. ${ }^{*} P<0.05$ ethanol vs. control. 


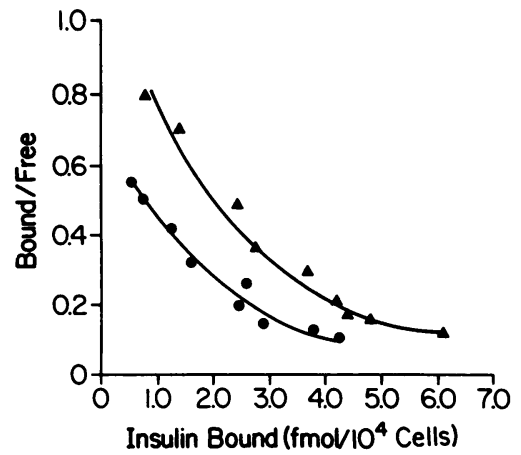

Figure 11. Scatchard plot of insulin binding to intact fetal hepatocytes. Cells were treated as described in the legend for Fig. 6. Hepatocytes had no prior exposure to insulin. Ethanol exposure was for $24 \mathrm{~h}$ $(1.7 \mathrm{mg} / \mathrm{ml})$. Ethanol cells are identified by filled triangles $(\Delta)$ and control by filled circles (๑). Each point repre-

sents a mean of five values. $P<0.05$, ethanol vs. control for all points.

fall over a 24-h period, resulting in upregulation. However, inclusion of higher levels of EGF in the medium (5 or 10 $\mathrm{ng} / \mathrm{ml}$ ) and shorter feeding intervals had no effect on the increase in binding. Direct ELISA of EGF levels after $24 \mathrm{~h}$ of culture further revealed no significant differences between control and ethanol exposed cells. Finally, exposure of both experimental groups to controlled concentrations of EGF did not abolish the observed differences. It is difficult, therefore, to explain how such upregulation could account for the increased binding observed. What was seen is more consistent with an alteration in the "set point" of such EGF-mediated receptor modulation, with an increase in total receptor on the surface.

Total EGF-R levels could increase if receptor synthesis was enhanced without a compensatory increase in degradation. Our data do not rule out such an effect. The increase necessary to double the receptor amount over a 24-h period is relatively small (6-7\% per $\mathrm{h})$. Such a small increase in rate could occur and not be detectable. Because of potential differences in methionine transport (8), intracellular amino acid pool sizes (38), and turnover rates of cellular protein in alcohol-exposed cells, an exact comparison of receptor synthesis with control cells is difficult. At the early time points, where initial rates of incorporation should reflect rate of synthesis of EGF-R most closely, there was no detectable difference in appearance of ${ }^{35} \mathrm{~S}$ counts in immunoprecipitated EGF-R between control and ethanol exposed cells. After labeling for 12 or more hours, increased accumulation of radiolabel in EGF-R in ethanol exposed cells was seen, reflecting not only synthesis, but turnover and pool size of the receptor. As an additional indicator, EGF-R mRNA levels were measured and found to be increased by $62 \%$. However, total cellular RNA, the constituitively expressed $\beta$-actin mRNA and EGF-R mRNA were all increased proportionally in ethanol exposed cells. Thus, the increase in EGF-R mRNA is nonspecific, but could nevertheless result in increased EGF-R synthesis. No definite evidence for this could be demonstrated.

A role for impaired internalization as a mechanism leading to EGF-R accumulation on the cell membrane is attractive in light of the known membrane disordering effects of ethanol and previous reports of ethanol-related impairment of receptor mediated endocytosis $(30,31)$. Subsequent experiments indicated that this was the case with EGF and the fetal hepatocyte. Receptor mediated endocytosis exhibits first order kinetic behavior which is accurately described by the fractional endocytotic constant $\left(K_{\mathrm{e}}\right)(29)$. Initial rates of internalization $\left[0.056 \pm 0.025 \mathrm{SE}\right.$ vs. $0.057 \pm 0.035 \mathrm{SE}\left(\mathrm{fmol} / \mathrm{min}\right.$ per $10^{5}$ cells $)$ for control and ethanol, respectively] were similar, while the ultimate fraction internalized (57 vs. $31 \%$ ) was markedly reduced in ethanol exposed cells. Expressed in terms of $K_{\mathrm{e}}$, ethanol exposure reduced this kinetic constant from $0.061 \pm 0.008$ $\mathrm{SE}$ to $0.0305 \pm 0.006 \mathrm{SE}$. Similar effects have been reported for asialo-orsomucoid $(30,31)$. Reduced fractional internalization, with or without a small increase in receptor synthesis, would result in an increase in EGF-R pool, as internalization precedes degradation. An alternate explanation is the accumulation of a population of receptor on the cell surface which accounts for the overexpression of EGF binding. These receptors bind EGF identically to the usual receptor (i.e., there is no appearance of a new receptor population on Scatchard plots), yet they are not efficiently internalized upon binding EGF. The experiments reported herein cannot distinguish between these two mechanisms.

Such a kinetic effect does not identify the point of ethanol effect. Potential sites of interference with endocytosis include receptor migration, formation of the coated pit by association of clathrin with the membrane, or budding of the endocytotic vesicle. The endocytotic process has been demonstrated to be exquisitely sensitive to changes in intracellular $\mathrm{pH}$ and potassium levels $(32,33)$, as well as the $\mathrm{pH}$ of the endosome (34). The parallel enhancement of transferrin, insulin and glucagon binding, in our hands, and the effects on asialoglycoprotein handling in other reports $(30,31)$ argue for a relatively nonspecific effect of ethanol on some key membrane function. As a final note, several groups have provided evidence that transmission of the mitogenic signal may be related to postendocytotic trafficking of the EGF-receptor complex (35-37). Thus, altered endocytosis that results in a reduction in intracellular receptor or redistribution of receptor may contribute to the ethanol-induced impairment of fetal hepatocyte replication.

\section{Acknowledgments}

Supported by research grants from National Institutes of Health (grant No. NIAAA 7R01 AA05814) and the Veterans Administration (Research Service, Audie L. Murphy Memorial Veterans' Hospital, San Antonio, TX).

\section{References}

1. Jones, K. L., and D. W. Smith. 1973. Recognition of the fetal alcohol syndrome in early infancy. Lancet. ii:999-1001.

2. Jones, K. L., D. W. Smith, C. N. Ulleland, and P. Streissguth. 1973. Pattern of malformation in offspring of chronic alcoholic mothers. Lancet. ii: 1267-1271.

3. Chernoff, G. F. 1977. The fetal alcohol syndrome in mice: an animal model. Teratology. 15:223-229.

4. Ellis, F. W., and J. R. Pick. 1980. An animal model of the fetal alcohol syndrome in beagles. Alcohol. Clin. Exp. Res. 4:123-134.

5. Randall, C. L., W. J. Taylor, and D. W. Walker. 1977. Ethanolinduced malformations in mice. Alcohol. Clin. Exp. Res. 1:219-224.

6. Henderson, G. I., A. M. Hoyumpa, C. McClain, and S. Schenker. 1979. Effects of chronic and acute alcohol administration on fetal development in the rat. Alcohol. Clin. Exp. Res. 3:99-106.

7. Abel, E. L., and B. A. Dintcheff. 1978. Effects of prenatal alcohol exposure on growth and development in rats. J. Pharmacol. Exp. Ther. 207:916-921, 1978.

8. Heitman, D. W., T. A. Frosto, S. Schenker, and G. I. Henderson. 1987. Stimulatory effects of ethanol on amino acid transport by rat fetal hepatocytes. Hepatology. 7:307-314. 
9. Yarden, Y., and A. Ullrich. 1988. Molecular analysis of signal transduction by growth factors. Biochemistry. 27:3113-3119.

10. Chin, J. H., and D. B. Goldstein. 1981. Membrane disordering action of ethanol: variation with membrane cholesterol content and depth of spin label probe. Mol. Pharmacol. 19:425-431.

11. Gonzalez-Calvin, J. L., J. B. Saunders, I. R. Crossley, C. J. Dickenson, H. M. Smith, J. M. Tredger, and R. Williams. 1985. Effects of ethanol administration on rat liver plasma membrane-bound enzymes. Biochem. Pharmacol. 34:2685-2689.

12. Leffert, H. L., and D. Paul. 1972. Studies on primary cultures of differentiated fetal liver cells. J. Cell Biol. 52:559-568.

13. Brengman, T. S., P. B. Lindquist, and R. Derynck. 1987. Different transforming growth factor - alpha species are derived from a glycosylated and palmitolylated transmembrane precursor. Cell. 48:429-440.

14. Blitzer, B. L., and C. B. Donovan. 1984. A new method for the rapid isolation of basolateral plasma membrane vesicles from rat liver. J. Biol. Chem. 259:9295-9301.

15. Laemmli, U. K. 1970. Cleavage of structural proteins during the assembly of the head of bacteriophage T4. Nature (Lond.). 227:680-685.

16. Gough, N. M. 1988. Rapid and quantitative preparation of cytoplasmic RNA from small numbers of cells. Anal. Biochem. 173:93-95.

17. Krawczyk, W., and C. Wu. 1987. Isolation of RNA for dot hybridization by heparin-DNAse I treatment of whole cell lysate. Anal. Biochem. 165:20-27.

18. Fleck, A., and H. N. Munro. 1962. The precision of ultraviolet absorption measurements in the Schmidt-Tannhauser procedure for nucleic acid estimation. Biochim. Biophys. Acta. 55:571-583.

19. Thomas, P. S. 1980. Hybridization of denatured RNA and small DNA fragments transferred to nitrocellulose. Proc. Natl. Acad. Sci. USA. 77:5201-5205.

20. Klausner, R., J. Van Renswoude, J. Harford, C. Wofsy, and B. Goldstein. 1985. Mathematical modeling of receptor-mediated endocytosis. In Endocytosis. I. Pastan and M. C. Willingham, editors. Plenum Press, New York. 259-279.

21. Haigler, H. T., F. R. Maxfield, M. C. Willingham, and I. Pastan. 1980. Dansylcadaverine inhibits internalization of ${ }^{125}$ I-epidermal growth factor in Balb 3T3 cells. J. Biol. Chem. 255:1239-1241.

22. Wiley, H. S., and D. D. Cunningham. 1982. The endocytotic rate constant. A cellular parameter for quantitating receptor-mediated endocytosis. J. Biol. Chem. 257:4222-4229.

23. Lowry, O. H., N. J. Rosebrough, A. L. Farr, and R. J. Randall. 1951. Protein measurement with the Folin phenol reagent. J. Biol. Chem. 193:265-275.

24. Carpenter, G. 1987. Receptors for epiderman growth factor and other polypeptide mitogens. Annu. Rev. Biochem. 56:881-914.

25. Henderson, G. I., R. V. Patwardhan, A. M. Hoyumpa, and S.
Schenker. 1981. Fetal alcohol syndrome: overview of pathogenesis. Neurobehav. Toxicol. Teratol. 3:73-80.

26. Henderson, G. I., R. V. Patwardhan, S. McLeroy, and S. Schenker. 1982. Inhibition of placental amino acid uptake in rats following acute and chronic ethanol exposure. Alcohol. Clin. Exp. Ther. 6:495-505.

27. Fisher, S. E., M. Atkinson, D. Van Thiel, E. Rosenblum, R. David, and I. Holzman. 1981. Selective fetal malnutrition: the effect of ethanol and acetaldehyde upon in vitro uptake of alpha amino isobutyric acid by human placenta. Life Sci. 29:1283-1288.

28. Draghi, E., U. Armato, P. G. Andreis, and L. Mengato. 1980. The stimulation by epidermal growth factor (urogastrones) of the growth of neonatal rat hepatocytes in primary tissue culture and its modulation by serum and associated pancreatic hormones. J. Cell. Physiol. 103:129-147.

29. Wiley, H. S. 1988. Anomalous binding of epidermal growth factor to A431 cells is due to the effect of high receptor densities and a saturable endocytic system. J. Cell Biol. 107:801-810.

30. Casey, C. A., S. L. Kragskow, M. F. Sorrell, and D. J. Tuma. 1987. Chronic ethanol administration impairs the binding and endocytosis of asialorsomucoid in isolated hepatocytes. J. Biol. Chem. 262:2704-2710.

31. Sharma, R. J., and D. A. W. Grant. 1986. A differential effect between the acute and chronic administration of ethanol on the endocytotic rate constant, $\mathrm{Ke}$, for the internalization of asialoglycoproteins by hepatocytes. Biochim. Biophys. Acta. 862:199-204.

32. Sandvig, K., S. Olsnes, O. W. Peterson, and B. van Deurs. 1987. Acidification of the cytosol inhibits endocytosis from coated pits. $J$. Cell Biol. 105:679-689.

33. Larkin, J. M., W. C. Donzell, and R. G. W. Anderson. 1985. Modulation of intracellular K+ y ATP: effects on coated pit function in fibroblasts and hepatocytes. J. Cell. Physiol. 124:372-378.

34. Maxfield, F. R., M. C. Willingham, P. J. A. Davies, and I. Pastan. 1979. Amines inhibit the clustering of alpha 2 -macroglobulin and EGF on the fibroblast cell surface. Nature (Lond.). 277:661-663.

35. Raper, S. E., S. J. Burwen, M. E. Baker, and A. L. Jones. 1987. Translocation of epidermal growth factor to the hepatocyte nucleus during rat liver regeneration. Gastroenterology. 92:1243-1250.

36. Kay, D. G., W. H. Lai, M. Uchihashi, M. N. Khan, B. I. Posner, and J. J. M. Bergeron. 1986. Epidermal growth factor receptor kinase translocation and activation in vivo. J. Biol. Chem. 261:8473-8480.

37. Matrisian, L. M., K. D. Rodland, and B. E. Magun. 1987. Disruption of intracellular processing of epidermal growth factor by methylamine inhibits epidermal growth factor-induced DNA synthesis but not early morphological or transcriptional events. J. Biol. Chem. 262:6908-6913.

38. Henderson, G. I., T. A. Frosto, D. W. Heitman, and S. Schenker. 1989. Ethanol stimulates leucine uptake by rat fetal hepatocytes via transstimulation. Am. J. Physiol. 256:G384-G389. 